\title{
Moving up and down in real space
}

\section{The verbal particles upp 'up' and ner 'down' and the typological profile of Swedish}

\author{
Åke Viberg \\ Uppsala University (Sweden)
}

The paper focuses on the role of the Swedish spatial particles upp 'up' and ner 'down' to signal the endpoint-of-motion in the description of motion situations and is based on Swedish original fiction texts and their translations into English, German, French and Finnish. Frequently the endpoint is marked with a locative preposition such as pa 'on' or $i$ 'in', and then a particle is required to signal change-of-place. In German and Finnish, the particle is often zero translated and change-of-place is indicated by case. The particle is often zero translated also in French, a $\mathrm{V}(\mathrm{erb})$-framed language. This leads to contrasts at the conceptual level since verticality is not expressed. The result points to radical intra-typological differences between $S$ (atellite)-framed languages in the expression of Path depending on general morpho-syntactic differences. Another important conclusion is that several different classes of motion verbs must be distinguished even in S-languages to describe the expression of change-of-place.

Keywords: multilingual contrastive study, lexical semantics, spatial particles, vertical movement, English/Finnish/French/German/Swedish

\section{Introduction}

The typological profile of a language is a kind of multilingual comparison that accounts for the distinctive character of the structure of a language in relation to other languages based on work in general typology and contrastive studies (Viberg, 2006, 2013a). The approach can be compared to Hawkins (1986) comparative typology and to the combinations of contrastive studies with other types of language comparison discussed in König (2012) and van der Auwera (2012).

This paper will account for the use of the Swedish spatial verbal particles upp 'up' and ner 'down' from this perspective and is part of a general study of such particles in Swedish (see Viberg, 2015a, 2017). Spatial verbal particles represent a prominent characteristic of English, German and Swedish, which will be contrastively compared in this study. To give perspective, data from French and Finnish are included but with a focus on correspondence at 
the conceptual level, since direct structural counterparts are missing in French and have an unclear grammatical status and relatively low frequency in Finnish.

\subsection{Earlier studies}

Verbal particles have been studied from many perspectives (see Cappelle, 2005 and Luo, 2019 for English). Particle placement has been a central topic in English (Gries, 2003) but also in the other Germanic languages including the alternation between free and bound forms (Dehé, 2015). In Swedish, the alternation between free forms (e.g. komma upp 'come up') and bound forms (e.g. uppkomma 'up-' + 'come', 'come into existence') was discussed as part of the general study of particles in Viberg (2017). Within a separate tradition, the central topic has been the semantic networks of the extended meanings of spatial particles since Lindner's (1981) seminal study of out and up. Swedish particles are studied in depth from the same perspective in a monograph by Strzelecka (2003). A third tradition in which particles play an important role is represented by the studies of the motion situation inspired by Talmy (1985). Particles figure in such studies as one of the realizations of path, although the question of their exact function has not always been addressed. This article will focus on the functions of upp and $n e r$ in descriptions of the motion situation.

Motion has been one of the most frequently studied semantic fields within lexical (or semantic) typology following Talmy $(1985,2000)$ and Slobin $(1996,2004)$, see IbarretxeAntuñano (ed. 2017) and Matsumoto and Kawachi (eds 2020) for a number of recent studies. Talmy's model of the motion situation can briefly be summed up as follows: The Figure is the moving entity or the entity which has a certain location. (Peter in Peter ran home and the book in The book is on the table). Ground refers to the Source, Goal, or Location with respect to which something moves or is located, and Path to the spatial relation between the Figure and Ground as this is expressed through satellites of the verb such as particles and prepositions or incorporated into verbs such as enter (IN) and descend (DOWN). The expression of Path forms the basis for the typological distinction between verb-framed languages (V-languages), where path of motion is encoded in the verb root (e.g. French monter 'move=up'), and satellite-framed languages (S-languages), where the path of motion is expressed in satellites outside the verb, such as particles (e.g. English go up). There is also a third type, equipollently-framed languages (E-languages), where Manner and Path are expressed in serial verb constructions.

The exact definition of 'satellite' has been discussed a great deal, but today any element outside the verb root is often regarded as a satellite, and this is the alternative that will be followed in this study. Another disputed point is the very existence of specific types, since the division forms a continuum. It is now generally agreed that most languages have constructions of several types. However, Talmy originally claimed that the classification should be based on the dominant type of construction in a language and it remains an open question to what extent a dominant structure can be identified (see Slobin, 2017 for a recent review of various positions on these issues). The motion situation has also been approached from another direction by Beavers et al., 2009, who stress the importance of the motion-independent morphological, lexical and syntactic resources made available by individual languages to express spatial notions.

From a typological perspective, the motion situation in Swedish has been studied in Blomberg (2014), Fagard et al. (2013) and Viberg (1992, 2013a). Olofsson (2018) is a construction-grammar study of the motion situation based on large Swedish corpora (see also Teleman et al., 1999: 974-979.) The present study is a continuation of a corpus-based study in Viberg (2015a). Boers (1996) is a general study of the semantics of up and down in English. The motion situation in German is analyzed in Fagard and Kopecka (2021), and the situation in French is discussed from several new perspectives in Aurnague and Stosic (eds 2019) (see 
also Lebas and Cadiot, 2003 on monter 'move=up'). Finnish has words with a similar function as the Swedish particles upp and ner, but their grammatical status is unclear (Kolehmainen, 2005) and they have relatively low frequency. Finnish is interesting in particular because of its spatial cases and case-marked adpositions (see Huumo and Ojutkangas, 2006), which functionally fulfill some of the functions of particles in Swedish.

In the description of the Path, the spatial particles interact with other types of spatial markers that express other types of spatial concepts. Levinson and Wilkins (2006) identify three frames of reference. The intrinsic frame describes the relation between a Figure and a Ground, as for example the prepositions on and in (the apple in the bowl). The two other frames introduce an external reference point, which can be relative or absolute. The relative frame often refers to a viewer as in the stone in front of the tree (stone on the same side of the tree as the viewer) and the stone behind the tree (stone on the opposite side). The absolute frame refers to constant reference points, such as the cardinal points. Another example is the vertical updown axis. The opposition between UP and DOWN, which is the topic of this paper, can be defined relative to gravitation, for example by observing the dropping of a stone, which under ideal conditions will go straight down to the ground. Less ideally, up and down are used also with reference to motion along a slanted plane (The barrel rolled down the slope). Many of the corpus examples analyzed below will be of this non-ideal type.

\subsection{Aim and structure of the present study}

The present study will focus on the use of upp and ner with a literal spatial meaning to express motion (non-literal uses will be discussed in a separate paper). Several types of motion situations will be distinguished. Motion typically refers to change-of-place (displacement) as in Bert went from London to Berlin, but motion verbs can also be used to describe motion within an area (dynamic location) as in Bert strolled around in Berlin. With respect to changeof-place, a major distinction can be made between subject motion, when the entity that moves is realized as a subject as in Bert was running, and object motion as in Bert put the vase on the table, in which the motion of the object is profiled. When the motion verb is used in a sentence that refers to change-of-place, it is usually combined with an indication of the Path, which can be divided into three parts: Source - Transition - Goal (or Endpoint), as in Ann went out of the forest (Source), up through the flowery meadow (Transition) and down to the lake (Endpoint). Talmy (1985) also regarded stative Location as a type of motion situation: Ann was down at the lake.

The major research question is to answer what the exact functions of upp and ner are when they are used in descriptions of the motion situation and why in many cases they lack a direct counterpart as it turns out, not only in French but also in German and Finnish that are also satellite-framed. Related to this is the description of the crucial interplay between particles and prepositions in Swedish and English, and in German and Finnish with the addition of case. The role of the verb will also be studied since the different types of motion referred to by the verb have important consequences for the realization of Path even in a "satellite-framed" language such as Swedish.

The rest of the article is structured as follows. Section 2 will present data and method. Section 3 will discuss the use of upp and ner to describe subject motion followed by an account of Object motion in Section 4. The article ends with summary and discussion in Section 5. 


\section{Data and method}

Data will be taken from the Multilingual Parallel Corpus (MPC), which consists of extracts from 22 Swedish novels and their translations into English, German, French and Finnish. There are around 600,000 words in the Swedish original texts. The source texts are indicated with a text code based on the author's name (see Appendix in Viberg, 2013b for a list of the Swedish originals and the text codes).

The choice of novels as texts will make it possible to study the basic spatial uses in a systematic way and to situate the result within a broader typological framework (the Talmian tradition). A broad range of non-spatial extended meanings are also represented in the corpus, but they will be accounted for in a separate paper. A study of the basic meanings is a necessary first step to construct a complete network of all the meanings.

The use of translations in contrastive studies is a bone of contention, but a thorough discussion would require a separate paper. Very briefly put, the advantage of using translation corpora is that the expression of the same meaning in the same context can be compared across languages. The problem is that you must take various translation effects into account. You can counteract that by including originals and translations from both languages if you compare two languages (see Viberg, 2016a and 2020, for my view) but for a single multilingual study such as the present one the inclusion of originals in all languages represents a vast undertaking even if it may in principle be followed up in later studies or by comparison with other research of the languages in question.

\section{Subject motion}

The use of upp och ner interacts with the types of Prepositional Phrases (PPs) and other spatial expressions that are used.

\subsection{No PP}

In the simplest case, there is no other indication of the Path than the particle. Looking at such structures is a good starting point to find the closest translational correspondences. When the particle is the only spatial satellite of the verb, the Goal must be inferred from the speech situation or from the discourse context. In example (1), the Goal (the attic) has already been mentioned in the preceding context. The context is shown only for the English version, which is representative of all the languages. (KE is an example of the text codes referred to in Section $2, \mathrm{INF} 3=$ the third infinitive).

The entrance hall was lined with pale-green

boarding and bright-blue wallpaper;

behind a door steep stairs led up to the attic.

She went up to look

Hon gick upp och tittade. KE She went up and looked

Sie stieg hinauf und sah sich um. She stepped DIST-up /---/

Elle monta vérifier.

Annie meni ylös katso-ma-an.

Annie went up look-INF3-Illative

The most frequent translations are listed in Table 1 together with some representative examples of less frequent translations. 
Table 1. Major translations of Swedish upp when there is no PP.

\begin{tabular}{|c|c|c|c|c|c|c|c|c|c|c|c|}
\hline \multicolumn{12}{|c|}{ Total Swedish upp: 82} \\
\hline \multicolumn{3}{|c|}{ English } & \multicolumn{3}{|l|}{ German } & \multicolumn{3}{|l|}{ French } & \multicolumn{3}{|l|}{ Finnish } \\
\hline & $\mathrm{n}$ & $\%$ & & $\bar{N}$ & $\%$ & & $\bar{n}$ & $\%$ & & $\bar{n}$ & $\%$ \\
\hline up & 53 & 65 & (hin/her)auf- & 39 & 48 & (re)monter & 12 & 15 & ylös(päin) & 21 & 26 \\
\hline & & & hoch- & 12 & 15 & se lever & 11 & 13 & & & \\
\hline & & & (nach) oben & 7 & 9 & grimper & 8 & 10 & nousta 'rise' & 14 & 17 \\
\hline Total $^{1}$ & 53 & 65 & & 58 & 71 & & 31 & 38 & & 35 & 43 \\
\hline
\end{tabular}

The major English translation is $u p$, but verticality is also signaled in the verbs rise and climb $(7+6$ tokens). In German, the most frequent translation is the separable particle auf- which is often preceded by one of the deictic markers her- (proximal) or hin- (distal, DIST). The particle has the same form as the preposition auf 'on'. (The hyphen on the particle is used to show that it is bound to the verb in certain contexts.) The second most frequent correspondence is hoch- which is basically used as an adjective hoch 'high' but can also be used as a separable particle. In Finnish, the most frequent translation is ylös (including 3 ylöspäin 'upwards'). Ylös is in the now obsolete lative case, which indicated direction to a goal (Kolehmainen, 2005: 136). It is related to other words such as $y l i$ 'over', yllä 'on, over'. The second-most frequent translation is a verb indicating vertical movement nousta 'rise', which in some cases is combined with ylös. A look at the most frequent translations shows that the use of the closest correspondence of upp varies: English up (65\%), German (hin/her)auf- (48\%) and Finnish ylös (26\%). The correspondence is highest in English. As will be evident below, the correspondence is rather high in general for English when the particle has a literal spatial meaning, whereas the divergence is more pronounced between Swedish and the other languages.

As expected, there is no direct equivalent to upp in French, but vertical motion is primarily indicated in verbs. The major alternative is monter 'move=up', which, however, only accounts for $15 \%$ of the translations. There are other verbs, in particular se lever 'rise, lit. raise oneself', which also refers to vertical movement. Grimper 'climb up' is marked for manner but appears to indicate verticality as well ('move=up clambering'). None of these alternatives account for any large proportion of the translations, but they could be said to contribute to conceptual correspondence, since they indicate verticality. However, in many cases the translations into French lack any indication of verticality. Among verbs not marked for verticality, arriver 'arrive, come' (7 occurrences) and venir 'come' (4) are the most frequent. Like upp, these verbs indicate the reaching of the Goal but lack any indication of verticality. In a few cases, verticality is indicated in special phrases. For example, in one case, arriver is combined with en haut 'in high' and in one case with au sommet 'at/to the top'. Actually, there are other correspondents expressing UP besides the most frequent ones in all languages, but UP is not expressed in any way in many of the French and Finnish examples, so, to a great extent, correspondence is lacking even at the conceptual level.

Ner (with the alternative form ned) follows the same pattern as upp. In (2), ner is translated with a particle except in French, where the Path is incorporated in the verb descendre 'move=down'. In German, unter- 'down' is combined with the deictic prefix her-. In Finnish, alas is the most direct equivalent of ner. (CONDitional is a mood realized as a suffix: -isi.) Like ylös, alas is the obsolete lative form of a stem related to the noun ala 'area' and to spatial words such as alla 'under' and alta 'from beneath'.

\footnotetext{
${ }^{1}$ Percentages of the totals have been calculated separately and not by addition.
} 
Vad skulle hon säga när Mia kom ner? (KE)

What should she say when Mia came down?

Was sollte sie sagen, wenn Mia herunterkam?

Qu'allait-elle dire quand Mia descendrait?

Mitä hän sanoisi kun Mia tulisi alas?

What (s)he say-COND when Mia come-COND down

Table 2 shows the most frequent translations. The major French translations incorporate DOWN in a verb: descendre and tomber. (The forms redescendre and retomber with the repetitive prefix re-are included in the counts.) It must be remarked that when tomber is used, the Swedish original often contains falla 'fall'.

Table 2. The major translations of Swedish ner/ned when there is no PP.

\begin{tabular}{|c|c|c|c|c|c|c|c|c|c|c|c|}
\hline \multicolumn{12}{|c|}{ Total Swedish ner/ned: 67} \\
\hline \multicolumn{3}{|l|}{ English } & \multicolumn{3}{|l|}{ German } & \multicolumn{3}{|l|}{ French } & \multicolumn{3}{|l|}{ Finnish } \\
\hline & $\mathrm{n}$ & $\%$ & & $\mathrm{n}$ & $\%$ & & $\mathrm{n}$ & $\%$ & & $\mathrm{n}$ & $\%$ \\
\hline down & 43 & 64 & (he)runter- & 18 & 27 & descendre & 22 & 33 & alas & 23 & 34 \\
\hline downstairs & 2 & 3 & hinunter- & 13 & 19 & tomber & 11 & 16 & alaspäin & 3 & 4 \\
\hline & & & unter- & 5 & 7 & & & & & & \\
\hline Total & 45 & 67 & Total & 36 & 54 & Total & 33 & 49 & Total & 26 & 39 \\
\hline
\end{tabular}

English uses a structural equivalent most, followed by German and then Finnish, whereas the use of a Path-incorporating verb is the major strategy in French.

\subsection{Combinations with the locative prepositions $p a ̊$ and $i$}

A specific characteristic of Swedish is that the two most frequent locative prepositions $i$ 'in' and $p \stackrel{\circ}{a}$ 'on' are often used to indicate the endpoint of motion as in (3).

$$
\begin{aligned}
& \text { När det blivit riktigt mörkt gick vi upp på vinden. (KÖ) upp 'up' + på 'on'/Prep } \\
& \text { When it was properly dark we went up to the attic. } \\
& \text { Als es richtig dunkel war, gingen wir auf den Speicher. auf 'on'/Prep + Acc } \\
& \text { Ce soir-là, à la nuit tombée, nous montâmes au grenier. monter 'go=up' à 'at/to' } \\
& \text { Kun ilta oli pimennyt kunnolla, men-i-mme ylös vinti-lle } \\
& \text { go-PAST-1PL up attic-Allative ('onto') }
\end{aligned}
$$

In (3), på vinden (literally 'on the attic') indicates the endpoint of motion, but what does upp indicate? Upp indicates that the Endpoint is situated at a higher point than the point at which the motion started without indicating the resulting relation between the Figure and the Ground as the preposition på does. Thus upp describes the (final part of) the Path leading to the Endpoint of motion and will be referred to as the Trajectory for the purposes of this paper. As will be demonstrated, the reference to the Trajectory is often missing in the translations into German as in (3). In German, certain prepositions such as auf 'on' and in 'in' are combined with an NP in the accusative to indicate change-of-place and an NP in the dative to indicate Location and motion within an area. In Swedish, a directional particle such as upp is in principle obligatory to indicate change-of-place in combination with locative prepositions, whereas the use of a particle is optional in German. The use of a particle is optional also in Finnish, since Finnish has directional cases that indicate change-of-place: allative ('onto') and illative ('into') (see Huumo and Ojutkangas, 2006 for a more exact description). 
Figure 1 shows the basic way of signaling motion UP and DOWN in Swedish in sentences with subject motion verbs.

\begin{tabular}{|l|l|l|l|l|l|}
\hline Concepts & Figure & $\begin{array}{l}\text { Motion } \\
+ \text { Manner }\end{array}$ & Trajectory & $\begin{array}{l}\text { Endpoint/ } \\
\text { Location }\end{array}$ & Ground \\
\hline $\begin{array}{l}\text { Phrase } \\
\text { Structure }\end{array}$ & NP & Verb & Particle & [Prep & \multicolumn{2}{|c|}{ NP]PP } \\
\hline & $\begin{array}{l}\text { Linda } \\
\text { Linda }\end{array}$ & $\begin{array}{l}\text { gick } \\
\text { went }\end{array}$ & $\begin{array}{l}\text { upp } \\
\text { up }\end{array}$ & $\begin{array}{l}\text { på } \\
\text { on }\end{array}$ & $\begin{array}{l}\text { vinden } \\
\text { the attic }\end{array}$ \\
& $\begin{array}{l}\text { Lena } \\
\text { Lena }\end{array}$ & $\begin{array}{l}\text { sprang } \\
\text { ran }\end{array}$ & $\begin{array}{l}\text { ner } \\
\text { down }\end{array}$ & $\begin{array}{l}\text { i } \\
\text { in }\end{array}$ & $\begin{array}{l}\text { källaren } \\
\text { the cellar }\end{array}$ \\
& $\begin{array}{l}\text { with directional preposition: } \\
\text { Lukas } \\
\text { Lukas }\end{array}$ & $\begin{array}{l}\text { akte } \\
\text { went }\end{array}$ & $\begin{array}{l}\text { (upp) } \\
\text { (up) }\end{array}$ & $\begin{array}{l}\text { till } \\
\text { to }\end{array}$ & $\begin{array}{l}\text { tredje våningen } \\
\text { the third floor (with the lift) }\end{array}$ \\
\hline
\end{tabular}

Figure 1. The basic way to signal motion UP/DOWN in Swedish with subject motion verbs.

At the conceptual level (top row), Path has been broken down into Trajectory and Endpoint and on the level of phrase structure (simplified) to Particle and Preposition. In the present context, Trajectory refers to the meanings UP/DOWN, but with some adjustments several particles with other meanings could be included in the scheme. Table 3 shows the major types of translations of upp in combination with the locative preposition $p a^{\circ}$ 'on'. Total refers to the expressions that express the concept UP. Zero translations of upp are indicated at the bottom of the table as explained below.

Table 3. The major translations of upp in combination with the locative preposition $p a$ 'on'.

\begin{tabular}{|c|c|c|c|c|c|c|c|c|c|c|c|}
\hline \multicolumn{12}{|c|}{ Total Swedish upp på: 36} \\
\hline \multicolumn{3}{|l|}{ English } & \multicolumn{3}{|l|}{ German } & \multicolumn{3}{|l|}{ French } & \multicolumn{3}{|l|}{ Finnish } \\
\hline & $\bar{n}$ & $\%$ & & $\overline{\mathrm{n}}$ & $\%$ & & $\bar{n}$ & $\%$ & & $\bar{n}$ & $\%$ \\
\hline up on & 7 & 19 & (hin/her)auf- & 8 & 22 & monter & 11 & 31 & ylös(päin) & 4 & 11 \\
\hline up to & 8 & 22 & hoch- & 1 & 3 & grimper & 6 & 17 & & & \\
\hline up onto & 5 & 14 & & & & & & & & & \\
\hline up (Other) & & 6 & & & & & & & & & \\
\hline Total & 22 & 61 & & 9 & 25 & & 17 & 47 & & 4 & 11 \\
\hline & & & Zero+PPacc & 21 & 58 & & & & Zero+NPall & 18 & 50 \\
\hline & & & & & & & & & Zero+NPill & 5 & 14 \\
\hline
\end{tabular}

$U p$ appears in $61 \%$ of the English translations. One difference from Swedish is that pa often corresponds to a directional preposition to or onto. To has a direct correspondent in Swedish till but that preposition would often sound unidiomatic in examples such as (3). The complex preposition onto lacks a Swedish correspondence. A possible explanation could be that up does not signal direction as clearly as upp, since up can have a locative meaning, which is covered by the specific locative form uppe in Swedish. In German, the closest correspondence (hin/her)auf- only occurs 8 times. Frequently, the endpoint is marked simply by auf as a preposition and change-of-place is indicated by the use of the accusative case, whereas there is a Zero-translation of upp. This alternative is symbolized: Zero+PPacc in Table 3. Even when there is a particle, there is usually also a PP but that is not indicated in this and the following tables. 
In French, the most frequent translation is monter 'move=up', but it only occurs 11 times (31\%). Grimper 'climb' indicates manner but also expresses motion in the vertical direction. In Finnish, the particle ylös 'up' occurs only four times in the translations. In most cases, the concept UP is not expressed (Zero), but direction is expressed simply by one of the directional cases. Allative is used most frequently since it roughly means 'onto', but illative, which roughly means 'into' is also used, since the correspondence is not perfect. (This difference is not relevant for the present paper.) These alternatives are symbolized Zero + NPall and Zero + NPill in Table 3. An NP marked with a directional case is usually present also when there is a particle, but this is not indicated in the tables.

Example (4) shows the most typical correspondences of upp $i$.
Lorelei klättrade upp $\boldsymbol{i}$ helikoptern
Lorelei climbed up into the helicopter
Lorelei kletterte in den Hubschrauber
Lorelei monta dans l'hélicoptère
Lorelei kipusi helikopteriin

$$
\begin{aligned}
& \text { upp 'up'/Particle }+\mathrm{i} \text { 'in'/Prep } \\
& \text { in 'in'/Prep + NPAccusative } \\
& \text { monter 'go=up' dans 'in' } \\
& \text { Lorelei climbed helicopter-Illative }
\end{aligned}
$$

As can be observed in Table 4, up is often combined in English with the complex directional preposition into, which lacks a Swedish correspondent. The fact that up marks direction less clearly than upp may be at play even in this context. At a general level, the pattern is the same as for upp på. Verticality is in many cases Zero-translated in both German and Finnish and

\begin{tabular}{|c|c|c|c|c|c|c|c|c|c|c|c|}
\hline \multicolumn{3}{|l|}{ English } & \multicolumn{3}{|l|}{ German } & \multicolumn{3}{|l|}{ French } & \multicolumn{3}{|l|}{ Finnish } \\
\hline & $\bar{n}$ & $\%$ & & $\bar{n}$ & $\%$ & & $\bar{n}$ & $\%$ & & $\bar{n}$ & $\%$ \\
\hline up into & 11 & 32 & (hin/her)auf- & 4 & 12 & monter & 14 & 41 & ylös(päin) & 0 & 0 \\
\hline up in & 3 & 9 & hoch- & 1 & 3 & grimper & 3 & 9 & & & \\
\hline up (Other) & 9 & 26 & & & & & & & & & \\
\hline \multirow[t]{3}{*}{ Total } & 23 & 68 & & 5 & 15 & & 17 & 50 & & 0 & 0 \\
\hline & & & Zero+PPacc & 21 & 62 & & & & Zero+NPill & 22 & 65 \\
\hline & & & & & & & & & Zero+NPall & 4 & 12 \\
\hline
\end{tabular}
change-of-place is signaled by case, whereas French signals UP in the verb if the concept is signaled at all. Except for English, correspondence is low even at the conceptual level.

Table 4. The major translations of upp in combination with the locative preposition $i$ 'in'.

\begin{tabular}{|c|c|c|c|c|c|c|c|c|c|c|c|}
\hline \multicolumn{12}{|c|}{ Total Swedish ner/ned på: 24} \\
\hline \multicolumn{3}{|c|}{ English } & \multicolumn{3}{|l|}{ German } & \multicolumn{3}{|l|}{ French } & \multicolumn{3}{|l|}{ Finnish } \\
\hline & $\bar{n}$ & $\%$ & & $\mathrm{n}$ & $\%$ & & $\bar{n}$ & $\%$ & & $\bar{n}$ & $\%$ \\
\hline down on & 9 & 38 & (hin/her)unter- & 5 & 21 & descendre & 2 & 8 & alas & 2 & 8 \\
\hline down to & 2 & 8 & nieder & 2 & 8 & tomber & 3 & 13 & & & \\
\hline down onto & 1 & 4 & & & & & & & & & \\
\hline down & 2 & 8 & & & & & & & & & \\
\hline Total & 14 & 58 & & 7 & 29 & & 5 & 21 & & 2 & 8 \\
\hline Zero+onto & 3 & 13 & Zero+PPacc & 11 & 46 & & & & Zero+NPall & 11 & 46 \\
\hline & & & & & & & & & Zero+NPill & 4 & 17 \\
\hline
\end{tabular}

Like upp, ner/ned often lacks a direct correspondence in the translations except in English, when the particle is combined with på or $i$, see Table 5 for ner/ned på.

Table 5. The major translations of ner/ned in combination with the locative preposition $p a$ ' on'. 
Motion down is special since all the MPC languages have path verbs that incorporate DOWN as part of their meaning. In (5), Swedish uses the verb åka 'move', which is completely neutral with respect to verticality. (Typically, this verb refers to motion as a Passenger in a vehicle, but in this example, åka implies that the motion was accidental.) The other languages except English use a verb that means 'fall' and thus signal motion down in the verb.

Ett papper hade åkt ner på golvet. (CL) A paper had gone down on the floor A paper had fluttered to the floor.

Ein Blatt war auf den Boden gefallen. A sheet was on the floor (acc) fallen Un papier était tombé par terre.

Yksi papereista oli pudonnut lattialle. One of (the) papers was fallen floorAllative

The particle ner can also be combined with the preposition $i$ as in (6).
Han kröp ner $\boldsymbol{i}$ hålet. (AL2)
down in/Prep
He crept down into the hole.
Er kroch in das Loch.
in/Prep + Acc
Il est descendu dans le trou.
moved=down in/Prep
Hän ryömi kaivantoon.
(s)he crept ditch-Illative

The translations of the combination of $n e r+i$ 'in' follows the same pattern as ner + pa (see Table 6), but it should be noted that $n e r+i$ is much more frequent.

Table 6. The major translations of ner/ned in combination with the locative preposition $i$ 'in'.

\begin{tabular}{|c|c|c|c|c|c|c|c|c|c|c|c|}
\hline \multicolumn{12}{|c|}{ Total Swedish ner/ned $i: 82$} \\
\hline \multicolumn{3}{|l|}{ English } & \multicolumn{3}{|l|}{ German } & \multicolumn{3}{|l|}{ French } & \multicolumn{3}{|l|}{ Finnish } \\
\hline & $\bar{n}$ & $\%$ & & $\bar{n}$ & $\%$ & & $\bar{n}$ & $\%$ & & $\bar{n}$ & $\%$ \\
\hline down into & 22 & 27 & hinunter- & 7 & 9 & descendre & 15 & 18 & alas & 5 & 6 \\
\hline down to & 9 & 11 & nach unten & 5 & 6 & tomber & 16 & 20 & & & \\
\hline down in & 5 & 6 & & & & & & & & & \\
\hline down & 9 & 11 & & & & & & & & & \\
\hline Total & 45 & 55 & & 12 & 15 & & 31 & 38 & & 5 & 6 \\
\hline Zero+into & 20 & 24 & Zero+PPacc & 55 & 67 & & & & Zero+NPillat & 62 & 76 \\
\hline Zero+to & 3 & 4 & & & & & & & Zero+NPallat & 7 & 9 \\
\hline
\end{tabular}

A complicating factor in many of the examples is that there are occurrences of the relatively frequent path verbs sjunka 'sink' and falla 'fall' in the Swedish original texts. In addition, there are single occurrences of several more specific verbs that incorporate the concept DOWN in the verb (ramla, trilla, dimpa, dråsa, droppa, störta, rasa). Together, the path verbs indicating motion DOWN account for $21 \%$ (59/282) of the examples of $\mathrm{V}+n e{ }^{2}{ }^{2}$ When the path verb is combined with a locative preposition, the particle is not obligatory to signal change-of-place but ner/ned is often used, even if this may appear to be redundant. It would be too complicated

\footnotetext{
${ }^{2}$ Verbs incorporating DOWN appear to be common across languages. Viberg (2006: 113) suggested that the incorporation of Path in the verb root is variable and can be described as a markedness hierarchy, where verbs incorporating DOWN represent the first, unmarked step.
} 
to account for all combinations that occur. In Table 5 and 6 , the use of verbs of falling is not shown, except for French since the verb is the only way of indicating motion down in French.

$P \AA$ and $i$ account for a large proportion of the combinations of Particle + Preposition. Except for the two directional prepositions till 'to' and mot 'towards' that will be discussed in

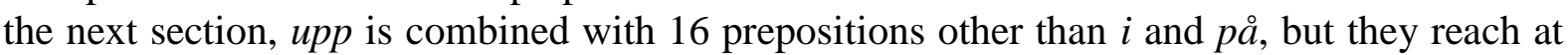
most a frequency of 5 occurrences except $u r$ 'out of' (13 occurrences). Ner/ned is combined with 12 other prepositions but only two appear more than five times: från 'from' (10) and över 'over' (8).

\subsection{Combinations with directional prepositions}

Swedish also has prepositions that express direction by themselves. When they are used, a particle is not needed to signal change-of-place. Such examples will therefore be treated rather briefly.

3.3.1 The reaching of a Goal indicated by till 'to'

The most basic directional preposition till 'to' refers to the reaching of a Goal, see (7).

Sedan lämnade han strandboden och gick upp till huset. (MF)

Then he left the boathouse and walked up to the house.

Dann verließ er das Strandhaus und ging hinauf zum Haus.

Puis, laissant le cabanon, il monta jusqu'à la Maison de Verre.

Sitten hän poistui rantavajalta ja meni talolle. [went house-Allative]

When till is used, no particle is obligatory in Swedish to mark the reaching of the goal, but upp and ner can be used to indicate motion in the vertical dimension as in (7). There are 43 occurrences of $u p p+$ till and 55 of ner/ned till.

\subsubsection{Motion towards a Goal indicated by mot 'towards'}

The preposition $m o t$ ' towards' expresses motion towards a Goal without indicating the reaching of the Goal, see (8).

(8) Och hon gick upp mot det gröna huset. (POE1)

And she walked up towards the green house.

Und sie ging $\boldsymbol{z} \boldsymbol{u}$ dem grünen Haus hinauf.

Et elle s'avançait vers la maison verte.

$\begin{array}{lllllll}\text { Ja } & \text { hän } & \text { lähti } & \text { nouse-ma-an } & \text { kohti } & \text { vihreä-tä } & \text { talo-a } \\ \text { and } & \text { (s)he } & \text { left } & \text { rise-3INF- } & \text { towards } & \text { green- } & \text { house-Partitive }\end{array}$

When upp is combined with mot, the resulting clause refers to an activity and is atelic. This can be tested by adding a durational adverb: Hon gick upp mot huset $\boldsymbol{i} 10$ minuter / She walked up towards the house for 10 minutes. In addition, upp and up are not stressed as a particle and function as spatial adverbs rather than as verbal particles. The same applies to ner in combination with mot. The total number of occurrences of upp + mot is 27 and of ner/ned mot 18. 


\subsection{Summing up subject motion}

At a general level, the degree of structural correspondence between Swedish and the other languages is summed up in Table 7 by looking at the extent to which the closest structural equivalents are used across all examples of subject motion. (For French, there is no direct structural equivalent, but the most frequent translation is shown instead.)

Table 7. The major structural equivalent of upp 'up' and ner/ned 'down' across all types of subject motion.

\begin{tabular}{|l|l|l|l|l|l|}
\hline & Swedish & English & German & French & Finnish \\
\hline & upp & up & *auf- & monter & ylös \\
$\mathrm{N}$ & 275 & 185 & 96 & 62 & 32 \\
$\%$ & 100 & 67 & 35 & 23 & 12 \\
& & & & & \\
& ner/ned & down & *unter- & descendre & alas \\
N & 282 & 177 & 100 & 75 & 42 \\
$\%$ & 100 & 63 & 35 & 27 & 15 \\
\hline
\end{tabular}

There is a sharp contrast between the three S-languages in spite of the fact that they all have a structural equivalent. English uses up and down as translations almost twice as often as German uses *auf- and *unter-. (The star indicates the various deictic markers.) The Finnish particles are used even less. As noted, their grammatical status is unclear, but there are no other conceptually corresponding elements in most examples. The difference is not confined to the choice of structural elements to express verticality but also represents an important conceptual difference, since in most cases verticality is not referred to in any other way. The proportion of Zero translations is particularly clear when change-of-place is indicated only by case in the translations of Particle + på/i into German and Finnish, see Table 8.

Table 8. Zero translation of upp and ner in constructions of the type Particle + på/i.

\begin{tabular}{|l|l|l|l|}
\hline & Swedish & German & Finnish \\
\hline & upp på/i; ner på/i & Zero + PPacc & Zero + NPallative/illative \\
$\mathrm{N}$ & 176 & 108 & 133 \\
$\%$ & 100 & 61 & 76 \\
\hline
\end{tabular}

The frequent use of a few subject-motion verbs is a conspicuous feature (see Table 9) that needs to be commented on. Even though there are as many as 76 verb types combined with upp and 77 combined with ner, the six most frequent verbs account for around $50 \%$ of the verb tokens. This reflects a general tendency for a few verbs to dominate within their semantic fields in terms of frequency of occurrence. In the Swedish SUC corpus comprising around one million words from a variety of written registers, the two most frequent motion verbs, the nuclear verbs komma and gå, cover together more than $25 \%$ of the total number of motion verb tokens in the corpus (including all uses, not just the literal ones), and the ten most frequent motion verbs account for close to 50\% (Viberg, 2006: 114). 
Table 9. The most frequent subject-motion verbs used in combination with upp and ner in the MPC.

\begin{tabular}{|c|c|c|c|c|c|}
\hline \multirow{2}{*}{\multicolumn{3}{|c|}{$\begin{array}{l}U p p \\
\text { Total. }\end{array}$}} & \multicolumn{3}{|l|}{ Ner/ned } \\
\hline & & & & & \\
\hline Tokens & & 275 & & & 282 \\
\hline Types & & 76 & & & 77 \\
\hline gå & 'go, walk' & 57 & gå & 'go, walk' & 50 \\
\hline komma & 'come' & 41 & komma & 'come' & 24 \\
\hline klättra & 'climb' & 21 & falla & 'fall' & 19 \\
\hline fara & 'go/travel' & 13 & sjunka & 'sink' & 17 \\
\hline flyga & 'fly' & 9 & krypa & 'creep' & 13 \\
\hline åka & 'go, ride in a vehicle' & $\begin{array}{l}9 \\
150\end{array}$ & åka & 'go, ride in a vehicle' & $\begin{array}{l}12 \\
135\end{array}$ \\
\hline
\end{tabular}

The results can be compared to the study by Olofsson (2018), who looked at 17 constructions consisting of a verb followed by a particle and a PP, for example [V-runt-på] and [V-upp-till]. The type of motion was restricted to what I call subject motion. The primary focus of Olofsson's study was the productivity of the constructions measured as the type and token frequencies of the verbs. In this study, the combined frequency of the ten most frequent verbs amounted to $71 \%$, and the two most frequent verbs were gå and komma followed by åka 'go, ride in a vehicle'. The study was based on large samples from corpora, in total 22978 verb tokens (Olofsson, 2018, Table 5, p. 189).

\subsection{Non-vertical interpretations of upp and ner}

As discussed in Strzelecka (2003: 223-227), upp and ner do not always refer to motion along the vertical dimension when they refer to change-of-place. No attempt will be made to quantify all such cases systematically, since the justification of their interpretation often requires detailed discussion. One specific use that is relatively frequent in the MPC is geographic up/down. In Swedish, upp can refer to a place that is further north than the starting point (see 9). In a similar way, ner can refer to motion towards the south.

$$
\begin{aligned}
& \text { Det var ju därför Rebecka åkte upp till Kiruna, } \\
& \text { That's why Rebecka went up to Kiruna, } \\
& \text { Ja, und deshalb ist Rebecka nach Kiruna gefahren, } \\
& \text { C'est pour ça que Rebecka est partie à Kiruna, } \\
& \text { Sen takiahan Rebecka oli lähtenyt Kiirunaan, (Kiruna-Illative] }
\end{aligned}
$$

Table 10 accounts for the translation of geographic upp in descriptions of subject motion. As can be observed, only English uses the direct correspondent up as a translation more than in a few sporadic examples. In Finnish, the north is referred to in some translations (pohjoiseen 'north-Illative'). ${ }^{3}$

Table 10. Translations of Swedish geographic upp.

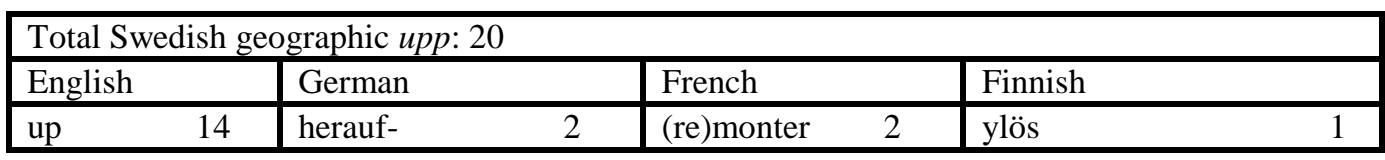

\footnotetext{
${ }^{3}$ Geographic north is described in a Swedish grammar (Viberg et al., $1984 \S 15.8$ ), which has been translated into all MPC languages. The translators in various ways corroborate the claim that geographic upp lacks a correspondent in French and Finnish. An example is given of the locative form uppe: Sommaren tillbringar de uppe i fjällen. They spend the summer up in the mountains. Il passent l'été (au nord) dans les montagnes.
} 
Upp and ner can also refer to the center of attention. A representative example is found in (10). (The English translation is quoted first to show the surrounding context.)

(10) The site was crowded with people. Cars drove up to the office and the people who got out were handsomely dressed, but Annie could see no faces, only eyes.

Bilar körde upp framför expeditionen. KE [Cars drove up in-front-of the office]

Autos fuhren vor der Anmeldung vor.

Des voitures se garèrent devant la réception.

[Cars were parked in-front-of the office $\left.{ }^{4}\right]$

Autoja ajoi toimiston eteen. [Cars drove office-GEN front-Illative]

It appears that "the office" referred to in the English version is not situated in a high location that would motivate the use of up. (As is often the case, it is difficult to be sure about the intended interpretation, but in any case, it is possible to give the example a natural interpretation under the assumption that no vertical displacement is involved.) The scene is described through the eyes of Annie. First a general view: The site was crowded with people. Then her attention is drawn to cars driving up and after that the focus narrows down to the people getting out of the cars and finally to an attempt to focus on their faces. German uses a particle (the final vor) that refers to motion forward, which is often used to indicate center of attention. ${ }^{5}$ (This will be studied in a separate article on the Swedish particle fram 'forward'.) Several other uses where upp refers to horizontal motion are discussed in Strzelecka (2003: 223-226) and in Ekberg (1997), but each of them has a low frequency in the corpus, which makes it difficult to make a contrastive comparison. At sea, for example, upp can refer to motion toward the wharf as in han girade upp mot bryggan 'he steered [up] towards the wharf' (Center) or to motion against the wind as in vända upp $i$ vind 'turn upwind'. As in English, you go up and down a stream. Both languages also have similar compound adverbs: upstream-downstream; uppströmsnerströms).

\section{Object motion}

The use of upp and ner to refer to object motion follows a similar pattern as for subject motion except that the interaction with different types of verbs is more complex. For that reason, some of the conclusions in this section will be tentative, but it is important to include object motion into the analysis since various types of caused motion is an understudied area, as pointed out by Matsumoto and Kawachi (2020). The major focus in Section 4 will be on phenomena that distinguish object motion from subject motion.

\subsection{The general picture}

The major types of translations are the same for object motion as for subject motion, but as will be discussed below, there are several types of object motion verbs in Swedish that do not require a particle to signal direction. In (11), which shows the general pattern, upp is translated by up in English, whereas the trajectory is incorporated into the verb in French. Monter 'move=up' can be used both as a transitive and as an intransitive verb. In German, direction is

\footnotetext{
${ }^{4}$ The verb garer '(to) park' is in the reflexive form (se garer), which makes the verb intransitive.

${ }^{5}$ French has a preposition (devant) and Finnish a postposition (eteen) which correspond to the Swedish preposition framför 'in front of' and not to upp.
} 
signaled by the accusative case and in Finnish by the allative case ('onto, to'), and the concept UP is not expressed in any way.

(11) Henry hade baxat upp TV:n på vinden (KE)

[Henry had lugged up the TV on the attic]

Henry had lugged the television up there

Henry hatte den Fernseher auf den Boden geschleppt

Henry avait monté la télévision $\boldsymbol{a u}$ grenier

Henry oli raahannut television vintille

[Henry had lugged TV attic-Allative ('to')]

The schema used for subject motion in Section 3.2 can be modified to describe object motion simply by inserting an object slot directly after the particle, see Figure 2.

\begin{tabular}{|c|c|c|c|c|c|}
\hline Agent & $\begin{array}{l}\text { Motion } \\
+ \text { Manner }\end{array}$ & Trajectory & Figure & Endpoint & Ground \\
\hline NP & Verb & Particle & NP & Prep-loc & NP \\
\hline $\begin{array}{l}\text { Henry } \\
\text { Henry }\end{array}$ & bar & upp & teven & på & vinden \\
\hline Ann & ställde & (ner) & väskan & på & golvet \\
\hline Ann & put ('stood') & down & the suitcase & on & the floor \\
\hline
\end{tabular}

Figure 2. The signaling of Path in object motion in Swedish.

Table 11 accounts for the most frequent correspondences of all categories of upp in combination with an object motion verb (both upp + no PP and upp + all types of PPs). Only the elements that refer to verticality are included.

Table 11. The major translations of upp in descriptions of Object motion.

\begin{tabular}{|c|c|c|c|c|c|c|c|c|c|c|c|}
\hline \multicolumn{12}{|c|}{ Total Swedish upp: 195} \\
\hline \multicolumn{3}{|l|}{ English } & \multicolumn{3}{|l|}{ German } & \multicolumn{3}{|l|}{ French } & \multicolumn{3}{|l|}{ Finnish } \\
\hline & $\mathrm{n}$ & $\%$ & & & $\%$ & & $\mathrm{n}$ & $\%$ & & $\mathrm{n}$ & $\%$ \\
\hline up & 117 & 60 & (hin)auf- & 31 & 16 & (re)monter & 20 & 10 & ylös & 16 & 8 \\
\hline upstairs & 1 & & hoch- & 38 & 19 & soulever & 21 & 11 & ylöspäin & 1 & 1 \\
\hline upright & 1 & & & & & hisser & 9 & 5 & pystyyn & 6 & 3 \\
\hline upward & 1 & & & & & dresser & 3 & 2 & & & \\
\hline Total: & 120 & 62 & & 69 & 35 & & 53 & 27 & & 23 & 12 \\
\hline
\end{tabular}

Starting with English, it can be observed that up is a rather frequent translation of upp, whereas the closest German correspondent (hin)auf- accounts for only a small proportion, and even together with hoch- 'high' used as particle, vertical movement is expressed only in $35 \%$ the examples. In Finnish, ylös accounts for a still smaller proportion. There are a few other markers such as pystyyn 'upright', but in most cases verticality is not expressed. As with Subject motion, Zero translations of UP are frequent in German and Finnish and direction is signaled via the case system. In French, several verbs incorporating UP are used, but UP is rather frequently not expressed. The most frequent subject-motion verb monter 'move up' is used also as an object-motion verb, but other verbs referring to vertical movement are also used such as soulever 'lift', lever 'lift, raise', and hisser 'hoist' and dresser 'raise'. Actually, verbs of the latter type are used in all the MPC languages as can be observed in (12). 
Sedan lyfter han upp hunden och kramar om den. (PCJ2) [Then lifts he up the dog] Then he lifts up the dog and embraces it.

Dann hebt er den Hund hoch [Then lifts he the dog high]

Puis il soulève le chien [Then he lifts the dog]

Sitten hän nostaa koiran syliinsä [Then he lifts dog bosom-Illative-3Poss]

One thing that complicates the picture is the fact that some of the verbs that are used in the Swedish originals refer to motion in the vertical dimension and could be said to incorporate UP in their most unmarked use. The most frequent of these verbs in the present material is lyfta 'lift' ( 25 occurrences), followed by hissa 'hoist' (5), but both lyfta ner 'lift down' and hissa ner 'hoist down' are possible, and examples of these combinations appear in the MPC. It is open to discussion, whether a verb such as French soulever 'lift' should be counted as a correspondence of upp, even in the cases when the Swedish original contains lyfta. On the other hand, it is not quite satisfactory to count this as a case of Zero translation of upp, since the concept UP is present also in the French version. The situation in Finnish is also complex. In Finnish, the most frequent translation of lyfta 'lift' is nostaa, which is used 35 times as a translation, but only once in combination with ylös 'up' (and two with pystyyn). Nostaa (and its derived forms causative nostattaa and frequentative nostella) is used also as a translation of some non-directional Swedish verbs combined with upp. These and similar complications must be left for studies based on all occurrences of specific object-motion verbs in a corpus rather than on the particles.

The use of ner/ned 'down' in combination with a motion verb follows the general pattern and will not be commented on in detail. See Table 12.

Table 12. The major translations of ner/ned in descriptions of Object motion.

\begin{tabular}{|c|c|c|c|c|c|c|c|c|c|c|c|}
\hline \multicolumn{12}{|c|}{ Total Swedish ner/ned: 183} \\
\hline \multicolumn{3}{|c|}{ English } & \multicolumn{3}{|l|}{ German } & \multicolumn{3}{|l|}{ French } & \multicolumn{3}{|l|}{ Finnish } \\
\hline \multirow{5}{*}{ down } & $\mathrm{n}$ & $\%$ & & $\bar{n}$ & $\%$ & & $\bar{n}$ & $\%$ & & $\mathrm{n}$ & $\%$ \\
\hline & 91 & 50 & her-/r-/hinunter & 36 & 20 & descendre & 9 & 5 & alas & 26 & 14 \\
\hline & & & (hin-)ab & 17 & 9 & baisser & 7 & 4 & alaspäin & 4 & 2 \\
\hline & & & nieder- & 3 & 2 & plonger & 11 & 6 & & & \\
\hline & & & nach unten & 2 & 1 & & & & maahan & 6 & 3 \\
\hline \multirow[t]{3}{*}{ Total } & 91 & 50 & & 58 & 32 & & 27 & 15 & & 36 & 20 \\
\hline & & & Zero+PPacc & 73 & 40 & & & & Zero+NPill & 68 & 37 \\
\hline & & & & & & & & & Zero+NPall & 24 & 13 \\
\hline
\end{tabular}

In French, descendre 'move=down' can be used also as an object-motion verb, but baisser 'lower' and plonger 'dive, plunge' are also used approximately as frequently in the present material. The closest Finnish correspondents are alas 'down' and alaspäin 'downwards' do not reach a very high frequency. Maahan 'to the ground' [ground-Illative] has been included in the table as an example of a general noun inflected for case and used as a correspondence of ner. Zero translations of ner/ned and the use of case to signal change-of-place are frequent in German and Finnish also with this particle.

\subsection{The decisive role of object motion verbs}

Rather many different verbs are used to describe object motion but as can be observed in Table 13 the most frequent verbs account for a large proportion of all verbs. 
Table 13. The most frequent object-motion verbs used in combination with upp and ner in the MPC.

\begin{tabular}{|lll|lll|}
\hline upp & & ner/ned & & \\
Total tokens & & 195 & & & 183 \\
Total types & & 59 & & & 78 \\
& & & & & \\
lyfta & 'lift' & 25 & dra & 'pull' & 20 \\
dra & 'pull' & 20 & stoppa & 'put=stuff' & 14 \\
ta & 'take' & 10 & lägga & 'lay' & 13 \\
plocka & 'pick' & 8 & sticka & 'put=stick' & 11 \\
lägga & 'lay' & 9 & släppa & 'let go' & 10 \\
sätta & 'put=attach' & 9 & köra & 'drive' & 8 \\
& & & ställa & 'put=stand' & 7 \\
Total & & 81 & & & 83 \\
\hline
\end{tabular}

A special group that is characteristic only of upp is the verbs of taking (ta 'take', plocka 'pick' and fiska 'fish, acquire'). Most of the other verbs belong to basic groups of object motion verbs in Swedish. Verbs of pulling and pushing are represented by $d r a$ 'pull' in Table 13. These verbs in general require a particle to express change-of-place in combination with locative prepositions as in (13), which describes the pulling of a canoe out of the water onto the grass on the shore.

(13) När han skulle dra upp den $\boldsymbol{i}$ gräset (KE)

As he was about to pull the canoe up on the grass,

Als er das Kanu ins Gras ziehen wollte,

Au moment où il allait le tirer sur l'herbe,

Kun hän veti kanoottia ruohikkoon, [when (s)he pulled canoe grass-Illative]

A sentence without the particle upp such as in Han drog kanoten i gräset 'He pulled the canoe in the grass' rather describes an atelic situation where the canoe already is in the grass at the start of the motion. Another basic group of object-motion verbs that require a particle are verbs of carrying, such as bära in sentences like Ann bar upp resväskan på vinden, literally 'Ann carried up the suitcase on the attic'. Without the particle, this sentence would rather mean that Ann carried the suitcase around on the attic or sound odd. As discussed in Viberg (2015a), verbs of carrying and verbs of pulling and pushing describe co-motion of agent and object, which makes it possible to use such verbs to refer to motion within an area.

Another frequent type of object-motion verbs are the verbs of putting such as (in Table 13) lägga 'lay', sätta 'put-attach', ställa 'put-stand', stoppa 'put-stuff' and sticka 'put-stick'. Such verbs frequently identify the endpoint of motion with på and $i$ without using a particle, see (14).

Han hade ställt en panna på spisen. (POE)

He had put a pan on the range.

Er hatte einen Topf auf den Herd gestellt. auf/Prep + NPacc

Il avait posé une poêle sur la cuisinière.

Hän oli nostanut hellalle pannun. [(S)he was lifted stove-Allative pan-ACC]

Actually, verbs of putting are frequently combined with locative prepositions in Swedish without using a particle (Viberg, 2015b: 230), and in that case Swedish looks like French, but it would be wrong to say that Swedish behaves like a V-language, since only change-of-place is indicated in the verb and not a specific Path, and unlike a typical V-language such as French, 
the Trajectory can easily be specified by adding a particle. Change-of-place of the object is rather a defining feature of a verb of putting that is present in all languages that have such verbs. German and Finnish do not treat verbs of putting separately but signal direction by case in the same way as with other verbs.

\subsection{A survey of the use of particles to represent the endpoint of motion in Swedish}

The major strategies used to express the reaching of the endpoint of motion are summed up in Table 14. (There are also other types of markers that have not been discussed in this paper, most importantly deictic adverbs: hit 'hither' and dit 'thither' and question words vart 'where to').

Table 14. The expression of endpoint of motion in Swedish.

To signal directional motion (Change-of-place) Swedish uses:

(i) Canonical Satellite-framed patterns:

- A directional particle alone: Peter gick upp. 'Peter went up'

- Directional particle+ Locative preposition: Peter gick upp på vinden. 'Peter went up to the attic'

- $\quad$ (Particle) + Directional Prep: Peter gick (upp) till huset på kullen. 'Peter went (up) to the house on the hill'

(ii) Non-canonical patterns: (Particle) + Locative preposition

- Verbs of falling: Peter trillade (ner) $i$ vattnet. 'Peter fell (down) in(to) the water'

- Verbs of throwing: Peter kastade boken i papperskorgen. 'Peter threw the book in(to) the wastepaper basket'

- Verbs of putting: Peter la boken på bordet. 'Peter put the book on the table'

- Verbs of pouring: Peter hällde vatten i flaskan. 'Peter poured water in(to) the bottle'

The canonical satellite-framed patterns require that all elements that indicate the Path appear outside the verb as satellites of some type. In Swedish, directional particles such as upp and ner play a crucial role to indicate change-of-place unless there is a directional preposition such as till 'to'. Verb-framed patterns are non-canonical in Swedish, but there are a number of path verbs. The most important group is the verbs of falling that clearly incorporate DOWN in their meaning as in a V-framed language. It should be noted that they rather often are combined with the particle ner/ned in spite of the fact that verticality is already indicated by the verb. Obviously, regularization also plays a role. Since particles are required in many other cases, there is a tendency that the combination Particle + Preposition is used whenever it can be used. Among the object motion verbs there are also verbs that refer to vertical motion, but as discussed above, many of these verbs require separate analysis since UP appears to represent only a default in verbs such as lyfta 'lift' and hissa 'hoist'. There are also a number of object motion verb such as the verbs of putting that do not indicate any particular Path but nevertheless indicate change-of-place of the object when combined with a locative PP without requiring a directional particle. These verbs share the characteristic that they do not refer to co-motion of 
the Agent. German and Finnish do not treat such verbs differently but indicate change-of-place explicitly by case in the ordinary way. Verbs that presuppose co-motion of the Agent such as the verbs of carrying and the verbs of pulling and pushing require a directional particle in Swedish to avoid that the sentence is interpreted as motion within an area.

\subsection{Pouring: a case of reconceptualization across languages}

In Swedish, pouring fits into the general picture of object motion but was not included in the count presented in Table 11. Pouring will be presented separately in this section, since the translations into the other languages to a great extent are based on different types of metonymy or a reconceptualization of the motion event as another type of event. Pouring basically refers to the caused motion of liquid from one container_1 held in the hand into another container_2 by tilting container_1. This basic conceptualization is shared by all the languages to be discussed below. However, a complex situation is often referred to by simply mentioning some salient subevent and leaving to the interpreter to fill out the rest. This is a kind of metonymy (subevent for event, pars pro toto). The Swedish sentence Åke hade hällt upp whisky [Åke had poured up whiskey] in (15) refers to the rising of the liquid in container_2 without explicitly mentioning any container.
Åke hade hällt upp whisky och satt fram knäckebröd och öl. (KE)
Åke had poured out whisky and put out crispbread and beer.
Åke hatte Whisky eingeschenkt
Åke avait versé du whisky
Åke oli kaatanut viskiä laseihin

Languages differ with respect to what elements they choose to express explicitly. In English, pour out refers to the result of tilting container_1 and the rest must be inferred. In both German (einschenken 'in-serve') and Finnish (kaataa lasei-hin 'pour glasses-Illative), reference is made to the motion of the liquid into container_2, which is explicitly mentioned in Finnish but understood in German. In French, only the liquid is explicitly mentioned (verser $d u$ whisky 'pour whiskey'). See Table 15. In Swedish, the verb slå 'hit' is frequently used as a (near) synonym to hälla 'pour' and appears in the same constructions (Viberg, 2016b: 207-208).

Table 15. The major translations of hälla upp/ slå upp (a liquid) in the MPC.

\begin{tabular}{|ll|ll|ll|ll|}
\hline \multicolumn{2}{|l|}{ Total Swedish hälla upp/slå upp: 19} & \\
\hline English & & German & & French & Finnish & \\
\hline pour out & 5 & einschenken & 9 & verser & 10 & kaataa + Zero & 10 \\
pour + Zero & 13 & eingiessen & 2 & servir & 7 & kaataa + NPillative & 6 \\
fill & 1 & auffüllen & 1 & & & kaataa + NPallative & 2 \\
\hline
\end{tabular}

In English, pour is used in combination with out in 5 examples, but in most cases it is used without any spatial particle. In German, ein- 'in' appears in the majority of the translations, but auf- 'up' appears in one example (auffüllen 'fill up'). French uses two verbs: verser 'pour' and servir 'serve' but no spatial markers. The latter represents a reconceptualization of the situation as serving something to someone (cf. German einschenken). Finnish uses the verb kaataa 'pour'. In 8 cases container 2 is indicated as a Goal with a directional case as the illative (-hin) in (15). The Swedish use of upp 'up' to indicate the rising of the liquid in container_2 appears to be very language specific. 


\section{Summary and discussion}

The study of the typological profile of a language differs from an ordinary contrastive study in several respects. It is multilingual, and it has as an aim to identify language-specific features and features that are characteristic of the language's general type in some sense. As stated in the beginning of this paper, the profile is based on work in general typology and contrastive studies. The first step is to identify the place of the structures being studied in a general typology. Spatial language has already been studied extensively from a typological point of view. In a broad survey of grammars of space in the languages of the world, Levinson and Wilkins (2006: 527) conclude that most languages that can be assigned to a certain type are Verb-framed and that the Germanic Satellite-framed pattern may be very restricted typologically. Thus, saying that Swedish is a satellite-framed language means that it differs in this respect from most of the world's languages.

The present study zooms in on four S-languages and points to important intra-typological differences with respect to the expression of spatial relations in the description of motion events.

- $\quad$ Swedish exploits directional particles such as upp and ner to signal change-of-place in combination with locative prepositions such as $p a ̊$ and $i$. There is a clear difference between Swedish and each of the other S-languages. English translations tend to contain to (into, onto) instead of a locative preposition. German frequently uses only a prepositional phrase and uses case to signal the distinction between location and change-of-place. Finnish frequently uses only an NP marked with a directional case. French, the only V-language in this study, as expected uses path verbs that incorporate UP or DOWN, but in many cases these two concepts are not expressed explicitly.

- The use of directional particles in Swedish to signal change-of-place leads to conceptual differences. The trajectories UP and DOWN are expressed more frequently to describe motion events in Swedish than in German, Finnish and French. For English, the situation is less clear, since the correspondent particles are used frequently, and it should not be expected that the closest correspondence is always used, even when languages are similar on a certain point.

Verbs play a prominent role to signal spatial relations (not just manner) even in an S-language.

- To begin, path verbs, in particular verbs indicating uncontrolled motion DOWN are relatively frequent in all the languages studied. This may be a universal tendency. There are also some verbs indicating motion UP in all the S-languages, but variation between such languages requires further study.

- In Swedish, several basic subfields of object motion verbs such as verbs of putting do not require spatial complements that signal change-of-place but often use complements that simply indicate location. German and Finnish in general use complements marked for direction also in this case.

- There are several more subfields of motion verbs that require separate study to give a full picture of the description of motion events. See Matsumoto and Kawachi (2020) for other such studies. 
- A general conclusion that can be drawn is that the indication of the endpoint of motion or final location (often signaled with a PP or, in Finnish, a case-marked NP) is more important than the signaling of the general orientation of the motion (the trajectory).

The original plan for this article was to cover all major uses of upp and ner, but for reasons of space, the account of non-spatial extensions will be published as a separate article that will also include a discussion of compound forms, in particular compound verbs, which represent another language-specific characteristic of Swedish (for a general overview, see Viberg, 2017). Another limitation of this study has to do with the multilingual approach which focuses on Swedish. The other languages have been discussed in less detail, but I feel confident that the broad differences that have been identified will hold and hope that the characterization of Swedish in this paper can be used to give a perspective on the other languages if they are analyzed in depth in other studies.

I will conclude by discussing some of the applications of the description of the typological profile of a language such as bilingualism and translation. Information about various areas of the typological profile of Swedish guided my own work on a Swedish grammar for second-language learners. My earlier contrastive-typological studies have been carried out in parallel with work on the acquisition of Swedish as a second language. A general conclusion from that work was that all learners tended to have problems acquiring language-specific features. In addition, there were problems characteristic of specific source languages. This calls for the combination of a typological and a contrastive approach. (cf. Filipović, 2017 on "applied language typology"). The situation in Sweden, where recent immigrants with many diverse first languages are often taught together in the same group, has parallels in many parts of the world. It will often not be possible to gain access to detailed contrastive descriptions of each language involved.

\section{References}

Aurnague, M. and Stosic, D. 2019. Recent Advances in the Study of Motion in French: A Survey. In M. Aurnague and D. Stosic (eds), 2-28.

Aurnague, M. and D. Stosic (eds). 2019. The Semantics of Dynamic Space in French: Descriptive, Experimental and Formal Studies on Motion Expression. Human Cognitive Processing 66. Amsterdam: Benjamins.

Beavers, J. Levin, B. and Tham, S.W. 2009. The Typology of Motion Expressions Revisited. Journal of Linguistics 46(2): 331-377.

Blomberg, J. 2014. Motion in Language and Experience: Actual and Non-actual Motion in Swedish, French and Thai. Travaux de l'Institut de Linguistique de Lund, 53. PhD thesis. The Faculties of Humanities and Theology.

Boers, F. 1996. Spatial Prepositions and Metaphor. A Cognitive Semantic Journey along the UPDOWN and the FRONT-BACK Dimensions. Tübingen: Gunter Narr.

Cappelle, B. 2005. Particle Patterns in English. A Comprehensive Coverage. PhD thesis. Katholieke Universiteit Leuven.

Dehé, N. 2015. Particle Verbs in Germanic. In Word-formation: An international handbook of the languages of Europe Vol. 1, P.O. Müller, I. Ohnheiser, S. Olsen and F. Rainer (eds), 611-626. Berlin/Boston: De Gruyter Mouton.

Ekberg, L. 1997. The Mental Manipulation of the Vertical Axis: How to Go from "up" to "out", or from "above" to "behind". In Lexical and syntactical constructions and the construction of meaning, M. Verspoor, K.D. Lee and E. Sweetser (eds), 69-87. Amsterdam and Philadelphia: Benjamins.

Fagard, B. and Kopecka, A. 2021. Source/Goal (A)symmetry. A Comparative Study of German and Polish. Studies in Language 45(1): 130-171. 
Fagard, B., Zlatev, J., Kopecka, A., Cerruti, M. and Blomberg, J. 2013. The Expression of Motion Events: A Quantitative Study of Six Typologically Varied Languages. Berkeley Linguistics Society 39: 364-379.

Filipović, L. 2017. Applied Language Typology: Applying Typological Insights in Professional Practice. Languages in Contrast 17(2): 255-278.

Gries, S. Th. 2003. Multifactorial Analysis in Corpus Linguistics: A Study of Particle Placement. [Open Linguistics Series] London: Continuum.

Hawkins, J.A. 1986. A Comparative Typology of English and German. Unifying the Contrasts. London and Sydney: Croom Helm.

Huumo, T. and Ojutkangas, K. 2006. An Introduction to Finnish Spatial Relations, Local Cases and Adpositions. In Grammar from the Human Perspective: Case, Space and Person in Finnish, ML. Helasvuo and L. Campbell (eds), 11-29. Amsterdam: Benjamins.

Ibarretxe-Antuñano, I. (ed.). 2017. Motion and Space across Languages. Amsterdam: Benjamins.

Kolehmainen, L. 2005. Präfix- und Partikelverben im deutsch-finnischen Kontrast. PhD thesis. Helsinki University.

König, E. 2012. Contrastive Linguistics and Language Comparison. Languages in Contrast 12(1): 3 26.

Lebas, F. and Cadiot, P. 2003. Monter et la constitution extrinsèque du référent." Langages 150: 9-30.

Levinson, S.C. and Wilkins, D. 2006. Patterns in the Data: Towards a Semantic Typology of Spatial Description. In S.C. Levinson and D. Wilkins (eds), 512-552.

Levinson, S.C. and Wilkins, D. (eds). 2006. Grammars of Space. Explorations in Cognitive Diversity. Cambridge: Cambridge University Press.

Lindner, S.J. 1981. A Lexico-semantic Analysis of English Verb Particle Constructions with out and up. Bloomington, IN.: Indiana univ. linguistics club.

Luo, H. 2019. Particle Verbs in English. A Cognitive Linguistic Perspective. Springer Verlag.

Matsumoto, Y. and Kawachi, K. 2020. Introduction. Motion Event Descriptions in Broader Perspective. In Y. Matsumoto and K. Kawachi (eds), 1-22.

Matsumoto, Y and Kawachi, K. (eds). 2020. Broader Perspectives on Motion Event Descriptions Human Cognitive Processing 69. Amsterdam: Benjamins.

Olofsson, J. 2018. Förflyttning på svenska. (Motion in Swedish - on productivity from a construction grammar perspective.) Göteborgsstudier i nordisk språkvetenskap 32. $\mathrm{PhD}$ thesis. University of Gothenburg.

Slobin, D.I. 1996. Two Ways to Travel. Verbs of Motion in English and Spanish. In Grammatical Constructions: Their Form and Meaning, M. Shibatani and S.A. Thompson (eds), 195-220. Oxford: Clarendon Press.

Slobin, D.I. 2004. The Many Ways to Search for a Frog: Linguistic Typology and the Expression of Motion Events. In Relating Events in Narrative: Typological and Contextual Perspectives, S. Strömqvist and L. Verhoeven (eds). 219-257. Mahwah, NJ: Lawrence Erlbaum Associates.

Slobin, D.I. 2017. Typologies and Language Use. In I. Ibarretxe-Antuñano (ed.), 419-446.

Strzelecka, E. 2003. Svenska partikelverb med in, ut, upp och ner. En semantisk studie ur kognitivt perspektiv. [Swedish phrasal verbs with in, ut, upp and ner. A semantic study from a cognitive perspective.] Skrifter utgivna av Institutionen för nordiska språk vid Uppsala universitet 62. PhD thesis. Uppsala University.

Talmy, L. 1985. Lexicalization Patterns: Semantic Structure in Lexical Forms. In Language Typology and Syntactic Description. Vol. 3, T. Shopen (ed.), 57-149. Cambridge: Cambridge University Press.

Talmy, L. 2000. Toward a Cognitive Semantics. Vol. II. Cambridge, MA: MIT Press.

Teleman, U., Hellberg, S., and Andersson, E. (eds). 1999. Svenska Akademiens grammatik. Del 2. Ord. Stockholm: Norstedts.

Van derAuwera, J. 2012. From Contrastive Linguistics to Linguistic Typology. Languages in Contrast 12(1): 69-86.

Viberg, Å. 1992. Universellt och språkspecifikt i det svenska ordförrådets organisation. Tijdschrift voor Skandinavistiek 13(2): 17-58.

Viberg, A. 2006. Towards a Lexical Profile of the Swedish Verb Lexicon. Sprachtypologie und Universalienforschung (STUF) 59(1): 103-129. 
Viberg, A. 2013a. Seeing the Lexical Profile of Swedish through Multilingual Corpora. The Case of Swedish $a k a$ and other Vehicle Verbs. In Advances in Corpus-based Contrastive Linguistics. Studies in Honour of Stig Johansson, K. Aijmer and B. Altenberg (eds), 25-56. Amsterdam: Benjamins.

Viberg, A. 2013b. Posture Verbs. A Multilingual Contrastive Study. Languages in Contrast 13(2): 139169.

Viberg, A. 2015a. Motion Verb Typology and the Expression of the Endpoint of Motion in Swedish. In Concepts and Structures - Studies in Semantics and Morphology. Studies in Linguistics and Methodology Vol. 8, M. Bloch-Trojnar A. Malicka-Kleparska and K. Drabikowska (eds), 209_ 229. Lublin: Wydawnictwo KUL.

Viberg, A. 2015b. Contrasts in Construction and Semantic Composition: Crosslinguistic Perspectives on the Verbs of Putting in English and Swedish. In Cross-linguistic Perspectives on Verb Constructions, S.O. Ebeling and H. Hasselgård (eds), 222-253. Newcastle upon Tyne: Cambridge Scholars Publishing.

Viberg, Å. 2016a. What Happens in Translation? A Comparison of Original and Translated Texts Containing Verbs Meaning SIT, STAND and LIE in the English-Swedish Parallel Corpus (ESPC). Nordic Journal of English Linguistics (NJES) 15(3): 102-148. Available at: https://njesjournal.com/ [Last accessed 3 June 2021].

Viberg, A. 2016b. Polysemy in Action: The Swedish Verb slå 'hit, strike, beat' in a Crosslinguistic Perspective. In The Lexical Typology of Semantic Shifts, P. Juvonen and M. Koptjevskaja-Tamm (eds), Cognitive Linguistics Research 58, 177-222. Berlin/Boston: de Gruyter Mouton.

Viberg, $\AA$. 2017. Contrasts in Morphology. The Case of UP/DOWN and IN/OUT as Bound Morphemes in Swedish and their English Correspondents. In Contrasting English and Other Languages through Corpora, M. Janebova, E. Lapshinova-Koltunski and M. Martinková (eds), 32-74. Newcastle upon Tyne: Cambridge Scholars.

Viberg, Å. 2020. Contrasting Semantic Fields across Languages. In New Approaches to Contrastive Linguistics. Empirical and Methodological Challenges, R. Enghels, B. Defrancq and M. Jansegers (eds), 265-312 [Series: Trends in Linguistics. Studies and Monographs (TiLSM), 336] Viberg, Å., Ballardini, K. and Stjärnlöf, S. 1984. A Concise Swedish Grammar. Stockholm: Natur \& Kultur. For information about versions in other languages, see: https://www.nok.se/titlar/laromedel-b2/malgrammatiken/ [Last accessed 3 June 2021].

Author's address

Åke Viberg

Department of linguistics and philology

Uppsala University

Box 635

SE-751 26 Uppsala

Sweden

Ake.Viberg@lingfil.uu.se 